\title{
Throughfall at an Abandoned Skid Trail in a Tropical Rain Forest in Peninsular Malaysia
}

\author{
Shoji NOGUCHI ${ }^{1,7 *}$, Junjiro N. NEGISHI ${ }^{2}$, Zulkifli YUSOP ${ }^{3}$, \\ Yoshiko KOSUGI ${ }^{4}$, Siti Aisah SHAMSUDDIN ${ }^{5}$ and Makoto TANI ${ }^{6}$ \\ ${ }^{1}$ Forestry Division, Japan International Research Center for Agricultural Sciences (Tsukuba, Ibaraki \\ 205-8686, Japan) \\ ${ }^{2}$ Graduate School of Environmental Science, Hokkaido University (Sapporo, Hokkaido 060-0810, \\ Japan) \\ ${ }^{3}$ Centre for Environmental Sustainability and Water Security (IPASA), Faculty of Civil Engineering, \\ University Technology Malaysia (UTM) (Johor Bahru, 81310, Malaysia) \\ ${ }^{4}$ Laboratory of Forest Hydrology, Graduate School of Agriculture, Kyoto University (Kyoto, Kyoto \\ 606-8502, Japan) \\ ${ }^{5}$ Forest Research Institute Malaysia (Selangor Darul Ehsan, Malaysia) \\ ${ }^{6}$ University of Human Environments (Okazaki, Aichi 444-3505, Japan)
}

\begin{abstract}
Knowledge of throughfall at abandoned skid trails in tropical forests is extremely scarce. Thus, throughfall was measured using 120 storage rain gauges set on a skid trail left abandoned 41 years after forest harvesting in the Bukit Tarek Experimental Watershed (BTEW) in Peninsular Malaysia. All trees of $\geq 1 \mathrm{~m}$ height in the plot were identified to the species level, and their diameter at breast height $(\mathrm{DBH})$ and height were measured. Vegetation along the skid trail comprises trees with smaller DBH $(0.2-31.0 \mathrm{~cm}$, with a mean of $2.0 \mathrm{~cm})$ and shorter height $(1.0-20.0 \mathrm{~m}$, with a mean of $2.8 \mathrm{~m})$ than those in the regenerated secondary forests of BTEW. The diversity (i.e. 43 families, 131 species) at the skid trail was similar to that in an old tropical forest at BTEW. The ratio of throughfall to gross rainfall $\left(T_{h} / R_{g}\right)$ for 84 rain events ranged from $27.4 \%$ to $204.7 \%$ with a mean and standard deviation of $98.1 \%$ and $33.2 \%$, respectively. We found that a considerable amount of rainwater dropped under bertam (i.e. Eugeissona tristis) and rattan (i.e. Daemonorops callicarpa, Calamus insignis) vegetation. The $T_{h} / R_{g}$ ratio weakly correlated with canopy openness. The mean $T_{h} / R_{g}$ ratio is the largest mean ratio ever reported for forests in Malaysia.
\end{abstract}

Discipline: Forestry and forest products

Additional key words: bertam, canopy openness, diversity, intense dripping, rattan

\section{Introduction}

Forest harvesting in Peninsular Malaysia is normally conducted using a combination of crawler tractor-winch lorry. This requires the construction of forest landings and logging roads. Without proper road planning and timber harvesting methods, severe soil disturbances may occur with the current method at forest landings, logging roads and skid trails (Baharuddin et al. 1995, Sidle et al. 2004).
These disturbed areas become sources of soil erosion and sedimentation, which are important issues in sustainable forest management. Therefore, there is a need to develop rehabilitation technology for the recovery of such disturbed areas (Kobayashi 2004), and knowledge of their hydrological characteristics will prove useful.

The Bukit Tarek Experimental Watershed (BTEW) in Peninsular Malaysia was established to quantify the effects of establishing a forest plantation on hydrological

Data were obtained during the project titled "Development of regeneration technology in consideration for preservation of forest environment functions (2001-2004)," which was funded by the Japan International Research Center for Agricultural Sciences. This study was also supported by the Japan Society for the Promotion of Science (JSPS) for KAKENHI (24255014).

Present address:

${ }^{7}$ Department of Disaster Prevention, Meteorology and Hydrology, Forestry and Forest Products Research Institute (Tsukuba, Ibaraki 305-8687, Japan)

*Corresponding author: e-mail noguchi@affrc.go.jp

Received 16 January 2017; accepted 28 June 2017. 
characteristics (Saifuddin et al. 1991). Some previous studies focused on the hydrological characteristics of skid trails and logging roads at the BTEW. The effects of logging roads and skid trails on sediment discharge were evaluated by Sidle et al. (2004). In addition, the contribution of intercepted subsurface flow to road runoff and sediment transport was evaluated based on the observation of hydrological and sediment fluxes at a 3-year old logging road (Negishi et al. 2008). Riparian buffers in tropical rain forests filter the sediment discharge from logging roads under suitable forest management (Gomi et al. 2006, Ohnuki et al. 2010). Ferns (e.g. Dicranopteris curranii) are typical plants that invade established logging roads and play an important role in determining nutrient conditions and temperature (Negishi et al. 2006). From the viewpoint of pedology-hydrology, differences in permeability and the effects of natural vegetation recovery on the hydrological response have been studied for various types of logging activities and abandoned skid trails (Ziegler et al. 2007).

After even 40 years, near-surface saturated hydraulic conductivity on an abandoned skid trail was still lower than that on undisturbed surface soils on adjacent forested hillslopes (Ziegler et al. 2007). Hence, throughfall on an abandoned skid trail in a tropical rain forests plays an important role in evaluating rainfall-runoff processes as well as determining nutrient conditions. However, knowledge of the spatial variability of throughfall on such skid trails is extremely scarce, not only in the BTEW but also in other tropical rainforests. Tropical rainforests have physical complex terrestrial ecosystems because of a heterogeneous canopy. Therefore, tree composition in the forests affects the spatial distribution of throughfall (Davie 2002). On the other hand, the logging in a tropical rainforest has an effect on canopy and stand structure (Okuda et al. 2003). These results suggest that knowledge of vegetation characteristics is important to evaluate throughfall at an abandoned skid trail in a tropical rainforest.

This study quantified the throughfall at an abandoned skid trail in a tropical rain forest in the BTEW. Our objectives were to (1) assess vegetation characteristics, (2) determine overall throughfall, and (3) identify the spatial distribution of throughfall at an abandoned skid trail in a tropical rainforest. Earlier, Yusop et al. (2003) had conducted interception measurement at a regenerated secondary forest in the BTEW. They found annual ratios of throughfall to rainfall over two years of $84 \%$ and $87 \%$. However, the ratio was not analyzed in detail on a daily basis. This study examined the variations of throughfall to rainfall ratio in the forest on a daily basis. Based on this result, we compared the throughfall at an abandoned skid trail and in a tropical rainforest.

\section{Material and methods}

\section{Study site}

The study was conducted at catchment C1 (32.8 ha) in BTEW $\left(3^{\circ} 31^{\prime} 30^{\prime \prime} \mathrm{N}, 101^{\circ} 35^{\prime} \mathrm{E}\right)$ located in Peninsular Malaysia (Fig. 1). It is a regenerated secondary forest that was logged in 1963 and classified as a lowland tropical rainforest. Representative forest species include Koompassia malaccencis, Canarium ssp., Santiria ssp., Eugenia spp., Dipterocarpus crinitus, Dipterocarpus kunstleri, and Shorea leprosula (Saifuddin et al. 1991). Based on an 11-year period of observation (1990-2000), the average annual precipitation is $2,321 \mathrm{~mm}$. The monthly rainfall distribution shows two peaks (in April and October) of maximum rainfall (Fig. 2). Rainfall is characterized by its short duration and high intensity (Noguchi et al. 1996). Daily evapotranspiration ranges from 2.7 to $4.9 \mathrm{~mm} \mathrm{~d}^{-1}$ (Noguchi et al. 2004a).

We selected a $120-\mathrm{m}$ long skid trail, left abandoned 41 years after forest logging in 1963, as a plot for the vegetation census (Fig. 1). The width of the skid trail ranged from 2.9 to $5.3 \mathrm{~m}$, with a mean width of $3.4 \mathrm{~m}$. The slope gradient is $5^{\circ}$. The plot was divided into $60 \times 2 \mathrm{~m}$ long blocks. The plot for throughfall observations was established within the vegetation plot.

Daily throughfall in a regenerated secondary tropical rain forest at the BTEW was measured earlier in another plot by Yusop et al. (2003). The plot was $30 \times 10 \mathrm{~m}$ in size, divided into small grids of $2 \times 2 \mathrm{~m}$, and located near the weir site (Fig. 1).

\section{Vegetation characteristics}

All trees $\geq 1 \mathrm{~m}$ in height in the plot were identified to the species level, and their diameter at breast height (DBH) and height were measured. The locations (block numbers) of the trees were also described.

In September 2004, hemispherical photographs through a fisheye converter (FC-E8, Nikon, Japan) mounted on a digital camera (Cool Pix 950, Nikon, Japan) were taken just above the center of three bottles used as simple storage rain gauges in the plot. In addition, hemispherical photographs were randomly taken at 14 soil survey points (Negishi et al. 2007) in the forest beside the skid trail. The openness of the hemispherical photographs was estimated using Hemiview 2.1 SR5 software (Delta-T Devices Ltd., UK). The vertex angle of the circular cone should be concentrated in a small area to investigate the relationship between canopy openness and throughfall distribution. Therefore, we decided upon an angle of $10.0^{\circ}$, which is similar to that used in a previous study in a tropical rain forest (Konishi et al. 2006).

\section{Hydrological observations}

We set up three bottles with funnels (each with an 


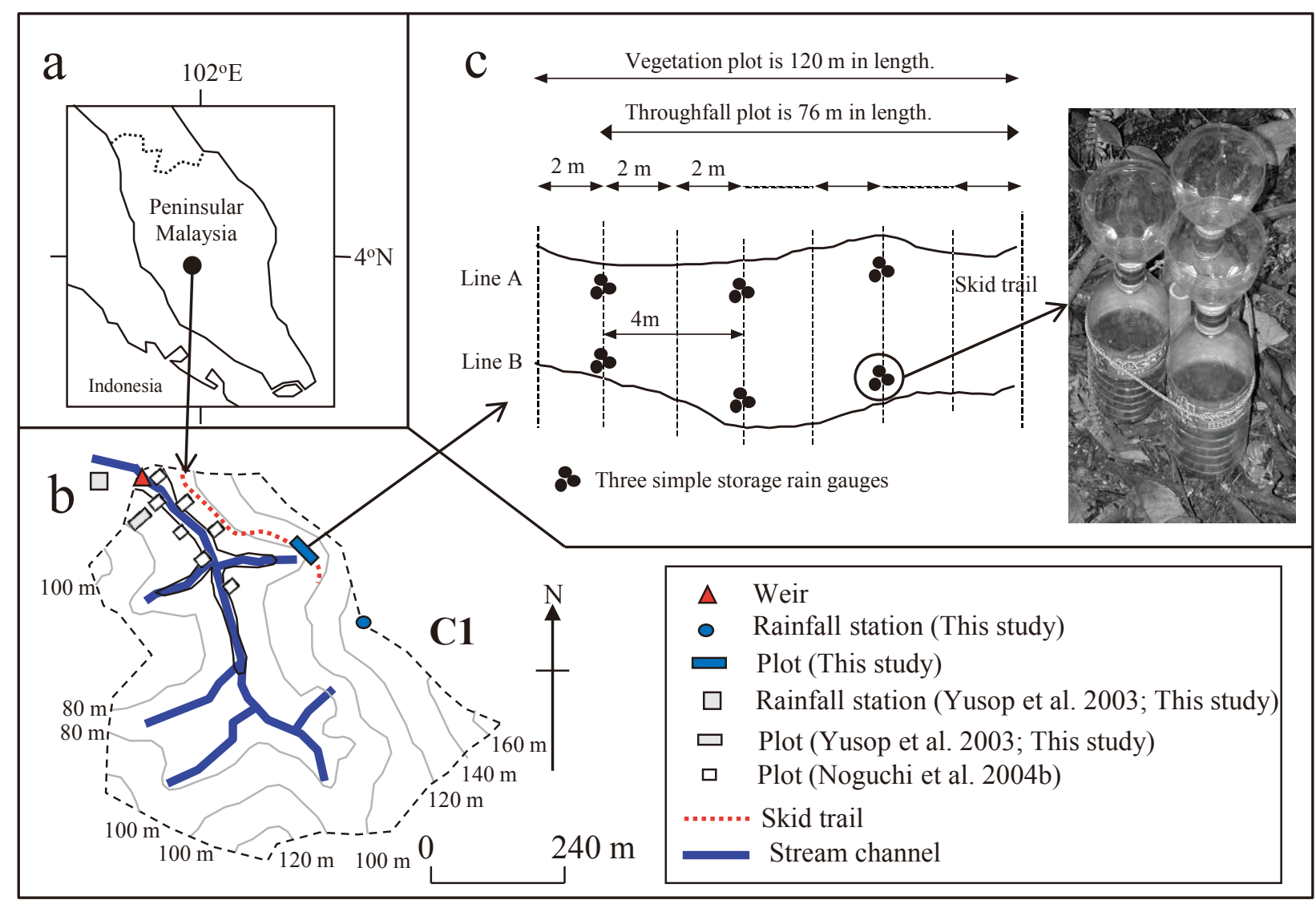

Fig. 1. (a) Location of the Bukit Tarek Experimental Watershed (BTEW) in Peninsular Malaysia, (b) Topography of the BTEW with contour interval of 20 meters and location of the study plots, (c) Layout of the tree census and the simple storage rain gauges for throughfall measurements at the plot and a photograph of the simple storage rain gauges.

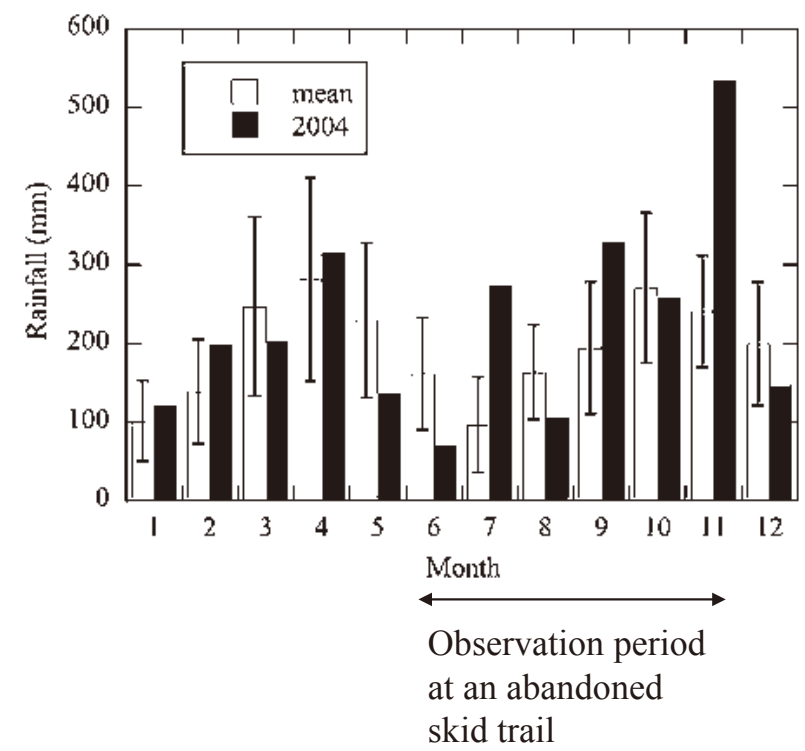

Fig. 2. Monthly rainfall distribution at the Bukit Tarek Experimental Watershed for 11 years (1990-2000: white bars) and in 2004 (black bars). Error bars show the mean \pm SD of monthly rainfall. area of $59.5 \mathrm{~cm}^{2}$; Fig. 1) as simple storage rain gauges (maximum amount: $336 \mathrm{~mm})$ to measure throughfall $\left(T_{h}\right.$, $\mathrm{mm})$ at 20 transects at 4-m intervals on both left and right (40 locations) sides of the skid trail in the plot. Thus, a total of 120 rain gauges covered an area of $7,140 \mathrm{~cm}^{2}$. Throughfall was measured 30 times from June to November 2004. However, the data from three rainfall events were excluded from analysis because of interference by animals and falling trees. Rainfall was measured using a tipping bucket rain gauge (Davis Ltd.) ( $R_{\text {rec }}$ : orifice area $=200 \mathrm{~cm}^{2}, 0.2 \mathrm{~mm}$ per tip) and five bottles with funnels (total orifice area $=297.5 \mathrm{~cm}^{2}$ ) as the simple storage rain gauges at the rainfall station located near the plot (Fig. 1). The storage rain gauges are the same as those used for throughfall. Rainfall was measured on the same day as the throughfall measurements. The rainfall data from the storage rain gauges were used as gross rainfall $\left(R_{g}, \mathrm{~mm}\right)$ in the analysis. Total rainfall, as measured using the tipping bucket gauge, was corrected using the following equation: $\left(R_{g}=1.03 R_{\text {rec }}-0.42, p<0.001, n=27, r^{2}=0.947\right)$. A rain event was defined as having $>0.2 \mathrm{~mm}$ of rain with 
an interval of more than $6 \mathrm{~h}$ from the last recorded rainfall using hourly data (Noguchi et al. 1996) based on the $R_{\text {rec }}$ data. Maximum rainfall intensity was corrected using the above equation.

We set up four storage rain gauges with a standard sharp edge copper funnel (with a total area of 1,297 $\mathrm{cm}^{2}$ ) to measure throughfall in the regenerated secondary forest near the weir (Fig. 1). Two of the storage rain gauges $\left(T_{h}-1\right.$, $\mathrm{T}_{\mathrm{h}}$-2) were mounted at fixed positions, whereas the other two $\left(T_{h}-3, T_{h}-4\right)$ were moved every fortnight at random coordinates. Daily rainfall was measured using a weighing-type recording rain gauge (Belfort Model) near the weir (Fig. 1). The throughfall was analyzed for duration between July 1991 and May 1993 in this study.

\section{Analysis}

The following equation was used to determine the number of collectors required to estimate the throughfall volume within a certain percentage of the mean at the desired confidence level used (Carlyle-Moses et al. 2004), which is based on equations used by Kimmins (1973) as follows:

$$
n^{\prime}=\frac{t^{2}{ }_{\left(\alpha, n^{\prime}-1\right)} C V^{2}}{C I^{2}}
$$

where $n^{\prime}$ is the number of collectors required, $t$ is the Student's $t$ value for a level of $\alpha$ with $n^{\prime}-1$ degrees of freedom, $C V$ is the coefficient of variation, and $C I$ is the confidence interval expressed as a percentage of mean throughfall. Using Eq. (1) to determine the number of collectors that would be required to sample throughfall effectively assumes that the spatial distribution of this flux is normally distributed.

The normality of all data was assessed by the Shapiro-Wilk test. The Mann-Whitney U test was applied to test the significance of differences between the two groups. The differences in throughfall at fixed positions and at random coordinates were compared with analysis of variance (ANOVA) with Scheffe's post hoc test for multiple comparisons. These analyses were conducted using SPSS version 20.0 software (SPSS Inc., Tokyo, Japan), and a p-value $<0.05$ was considered significant.

Forty hemispherical photographs were taken just above the center of three bottles used as simple storage rain gauges in the skid trail plot. The average throughfall measured from the three collecting bottles was used to analyze the relationship between canopy openness and throughfall.

\section{Results and discussion}

\section{Vegetation characteristics}

The tree census along the skid trail identified 676 individuals belonging to 43 families and 131 species. The most diverse family was Euphorbiaceae with 19 species, followed by Rubiaceae (18 spp.), Melastomataceae (8 spp.), and Myrtaceae (8 spp.). Both DBH and height of the trees exhibited an inverse J-shaped type of frequency distribution (Fig. 3). DBH ranged from 0.2 to $31.0 \mathrm{~cm}$, with a mean of $2.0 \mathrm{~cm}$ and standard deviation (SD) of $3.2 \mathrm{~cm}$. More than $92 \%$ of the trees had DBH of $<5 \mathrm{~cm}$. Tree heights ranged from 1.0 to $20.0 \mathrm{~m}$, with a mean of $2.8 \mathrm{~m}$ and SD of $2.6 \mathrm{~m}$. More than $86.5 \%$ of the trees were less than $4.0 \mathrm{~m}$ in height. There was a strong correlation $\left(H=2.013 D^{0.665}, n=676\right.$, $\left.r^{2}=0.873, p<0.001\right)$ between height $(H)$ and DBH of the
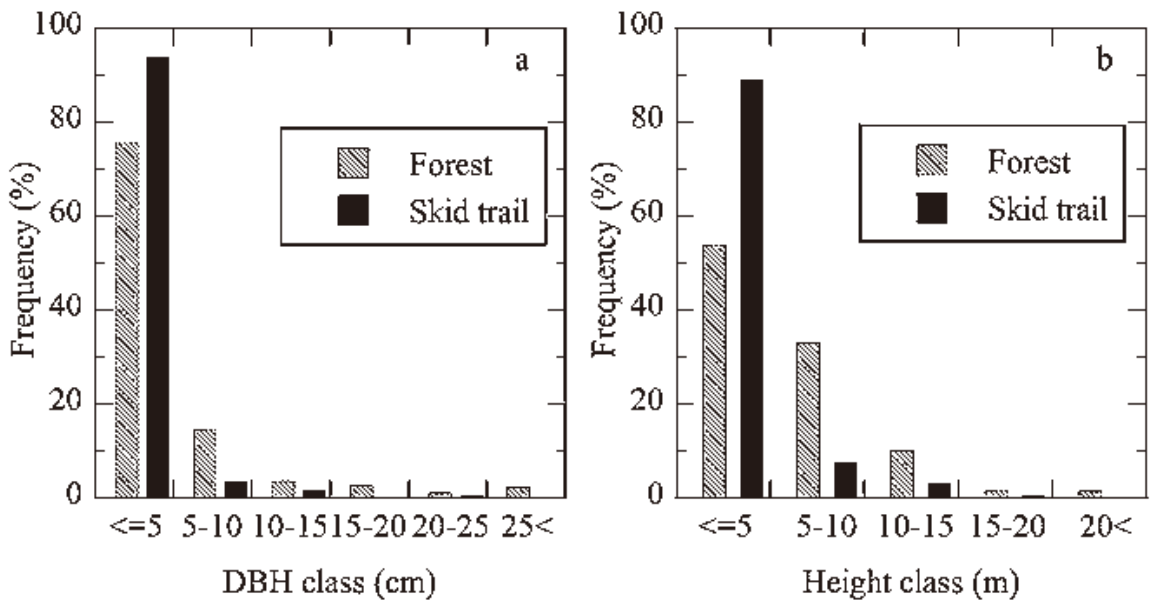

Fig. 3. Results of the tree census in the Bukit Tarek Experimental Watershed (a) Frequency distribution of diameter at breast height (DBH), (b) Frequency distribution of tree height. Results for the forest are based on those of Noguchi et al. (2004b). 
trees $(D)$.

In a previous study, Noguchi et al. (2004b) characterized tree species at seven plots (plot size: $10 \times 20 \mathrm{~m}$ ) in a regenerated secondary forest of the BTEW (Fig. 1). Their results showed a similar diversity in the forest (i.e. 40 families, 144 species) compared to that on the skid trail. In their study, the most diverse family was Euphorbiaceae with 23 species, followed by Lauraceae (10 spp.) and Rubiaceae (10 spp.). Moreover, DBH of the trees in their study was of a greater range $(0.2-75.8 \mathrm{~cm})$ and with a larger mean $(4.6 \mathrm{~cm})$ than those at the skid trail in this study (Fig. 3). In addition, trees in their study had a greater mean height (Noguchi et al. 2004b) than those at the skid trail in this study (Fig. 3).

Wiafe (2014) examined the tree species composition affected by the various levels of disturbances: i) undisturbed level (unlogged forest areas and twilight zones); ii) slightly disturbed level (skid trails and felled tree gap); and iii) heavily disturbed level (road, boarders and loading bays). Annonaceae, Sapindaceae and Sapotaceae were found at contributed to the undisturbed forest alone. However, these families were found on the abandoned skid trail in the BTEW. The dominant families with DBH greater than $10 \mathrm{~cm}$ on the skid trail were Annonaceae, Euphorbiaceae, Loganiaceae, Melastomataceae, Moraceae, Rutaceae, and Verbenaceae. These families form the main canopy (e.g. Monocarpia marginalis, Xylopia ferrugenia, Cyathocalyx pruniferus, Ptenandra echinata) and understorey (e.g. Baccaurea maingayi, Ptenandra echinata) species (Manokaran \& Swaine, 1994). Conversely, abundant canopy species before clear cutting, (e.g. Koompassia malaccensis) were classified as an emergent species group (Manokaran \& Swaine 1994). These species did not regenerate well in 23 years after clearing (Niiyama et al. 2003). Three mother trees of Koompassia malaccensis were found beside the plot and regenerated Koompassia malaccensis $(\mathrm{DBH}<10 \mathrm{~cm})$ were observed in the plot in the census. These results suggest that the composition of species diversity at the abandoned skid trail has shown some degree of recovery.

The canopy openness at the skid trail ranged from $0.3 \%$ to $50.4 \%$, with a mean and SD of 15.2 and $12.2 \%$, respectively (Fig. 4). In the regenerated secondary forest next to the skid trail, the canopy openness ranged from $0.2 \%$ to $42.9 \%$ with a mean and SD of $15.9 \%$ and $13.4 \%$, respectively (Fig. 4). The coefficient of variation $(\mathrm{CV}=80.3 \%)$ at the skid trail was almost similar to that under the canopy inside the forest $(\mathrm{CV}=84.5 \%)$. The canopy openness showed a normal distribution at the skid trail, but in the forest. No significant difference was observed between the canopy openness of the skid trail and that of the forest (Mann-Whitney U test, $p=0.937$ ).

There were some large trees $(\mathrm{DBH}>20 \mathrm{~cm}$ ) besides the throughfall plot at the skid trail, whose height ranged from 15.1 to $25.0 \mathrm{~m}$, with a mean of $21.5 \mathrm{~m}$ and SD of $3.3 \mathrm{~m}(n=13)$. The width of the crown of these trees ranged from $4.4 \mathrm{~m}$ to $11.6 \mathrm{~m}$, with a mean of $7.5 \mathrm{~m}$ and SD of $2.2 \mathrm{~m}$. Thus, part of the skid trail was covered with tall trees whose canopy extended from the adjacent forest. These results suggest that tall trees in the forest have an effect on canopy openness at the skid trail.

\section{Throughfall at an abandoned skid trail}

We measured the throughfall 27 times, which represents a total of 84 rain events (Table 1). The rain events ranged from 0.4 to $79.9 \mathrm{~mm}$, with a mean (SD) of $14.7 \mathrm{~mm}$ $(18.1 \mathrm{~mm})$. The maximum intensities of the rain events ranged from 0.2 to $47.9 \mathrm{~mm} \mathrm{~h}^{-1}$, with a mean (SD) of $9 \mathrm{~mm} \mathrm{~h}^{-1}\left(11.1 \mathrm{~mm} \mathrm{~h}^{-1}\right)$. The duration of rain events ranged from 1 to $16 \mathrm{~h}$, with a mean (SD) of $5.1 \mathrm{~h}(3.7 \mathrm{~h})$, and approximately $13 \%$ of the rain events fell within a 1 -h period.

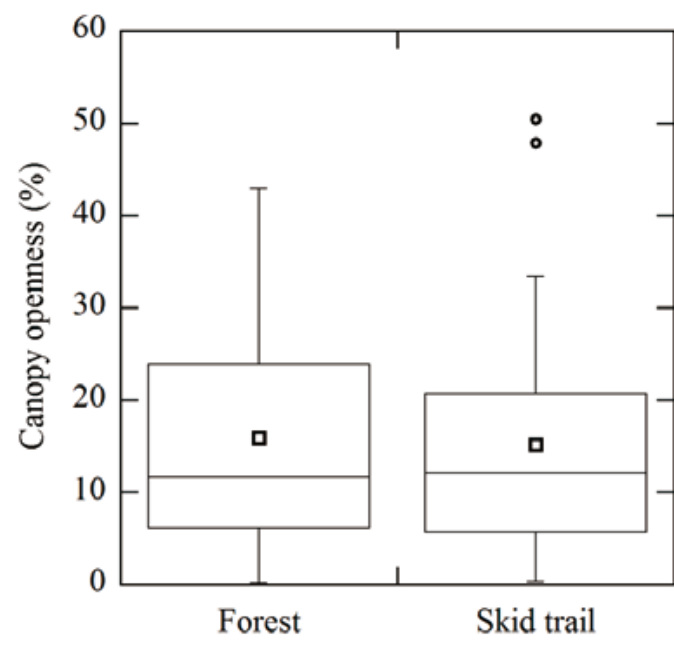

Box plot definition

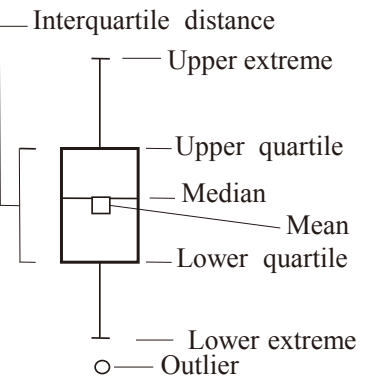

Fig. 4. Box plots for canopy openness in the forest and at the skid trail 
Table 1. Rainfall characteristics for 27 throughfall measurements

\begin{tabular}{|c|c|c|c|c|c|c|c|c|c|}
\hline No. & Start day & Stop day & $\begin{array}{l}\text { Gross rainfall } \\
(\mathrm{mm})\end{array}$ & $\begin{array}{l}\text { Max. intensity } \\
\quad\left(\mathrm{mm} \mathrm{h}^{-1}\right)\end{array}$ & $\begin{array}{c}\text { No. of } \\
\text { event }\end{array}$ & $\begin{array}{c}\text { Mean ratio of } \\
T_{h} / R_{g}(\%)\end{array}$ & $\begin{array}{l}\mathrm{CV}^{a} \\
(\%)\end{array}$ & $\begin{array}{l}\mathrm{CV}^{b} \\
(\%)\end{array}$ & $\begin{array}{c}\text { Mean } \mathrm{CV}^{c} \\
(\%)\end{array}$ \\
\hline 1 & 6-Jun & 7-Jun & 13.5 & 10.1 & 1 & 87.9 & 66.7 & 50.7 & 29.9 \\
\hline 2 & 7-Jun & 17-Jun & 7.0 & 7.0 & 1 & 33.8 & 65.6 & 60.8 & 40.1 \\
\hline 3 & 17-Jun & 28-Jun & 37.5 & 18.2 & 2 & 105.7 & 52.9 & 42.0 & 17.4 \\
\hline 4 & 28-Jun & 5-Jul & 90.0 & 47.9 & 2 & 89.4 & 52.0 & 46.5 & 15.8 \\
\hline 5 & 5-Jul & 6-Jul & 11.5 & 6.7 & 1 & 78.1 & 64.3 & 50.4 & 24.9 \\
\hline 6 & 6-Jul & 7-Jul & 55.5 & 12.5 & 1 & 95.9 & 60.9 & 51.8 & 26.3 \\
\hline 7 & 7-Jul & 14-Jul & 69.5 & 25.5 & 5 & 87.5 & 61.4 & 50.4 & 27.5 \\
\hline 8 & 14-Jul & 19-Jul & 48.0 & 32.8 & 4 & 97.9 & 69.5 & 59.1 & 25.2 \\
\hline 9 & 19-Jul & 28-Jul & 22.5 & 6.8 & 3 & 100.6 & 84.4 & 69.7 & 31.1 \\
\hline 10 & 28-Jul & 13-Aug & 11.8 & 6.1 & 4 & 61.2 & 98.1 & 96.3 & 27.5 \\
\hline 11 & 13-Aug & 18-Aug & 16.8 & 11.4 & 3 & 91.7 & 55.7 & 52.3 & 15.3 \\
\hline 12 & 18-Aug & 25-Aug & 30.1 & 27.6 & 3 & 120.6 & 49.5 & 45.7 & 11.9 \\
\hline 13 & 25-Aug & 1-Sep & 46.4 & 16.9 & 3 & 85.2 & 81.1 & 67.9 & 32.1 \\
\hline 14 & 1-Sep & 6-Sep & 46.2 & 25.0 & 2 & 95.7 & 46.7 & 41.5 & 11.7 \\
\hline 15 & 6-Sep & 8-Sep & 20.3 & 6.7 & 2 & 91.2 & 61.9 & 52.8 & 18.5 \\
\hline 16 & 13-Sep & 20-Sep & 95.5 & 42.5 & 5 & 102.6 & 38.5 & 33.9 & 15.4 \\
\hline 17 & 27-Sep & 4-Oct & 49.1 & 15.6 & 6 & 103.4 & 50.0 & 45.0 & 17.7 \\
\hline 18 & 4-Oct & 13 -Oct & 75.6 & 35.4 & 4 & 104.1 & 43.3 & 39.8 & 17.8 \\
\hline 19 & 13-Oct & 18-Oct & 49.1 & 16.8 & 3 & 77.3 & 54.6 & 48.1 & 18.2 \\
\hline 20 & 18 -Oct & $22-$ Oct & 50.4 & 12.5 & 4 & 96.4 & 64.9 & 45.8 & 26.0 \\
\hline 21 & $22-O c t$ & 23 -Oct & 7.2 & 4.1 & 1 & 115.3 & 65.0 & 44.9 & 113.7 \\
\hline 22 & 23 -Oct & $1-\mathrm{Nov}$ & 33.6 & 7.7 & 10 & 100.2 & 57.8 & 51.9 & 32.9 \\
\hline 23 & $1-\mathrm{Nov}$ & 2-Nov & 48.2 & 10.1 & 1 & 117.4 & 60.3 & 48.0 & 22.9 \\
\hline 24 & $2-\mathrm{Nov}$ & 4-Nov & 53.8 & 20.3 & 3 & 113.2 & 65.8 & 57.9 & 23.9 \\
\hline 25 & 4-Nov & 8-Nov & 104.7 & 34.6 & 4 & 92.2 & 54.5 & 47.5 & 13.1 \\
\hline 26 & 8-Nov & 11-Nov & 70.3 & 44.6 & 2 & 126.1 & 46.7 & 42.3 & 14.1 \\
\hline 27 & 22-Nov & 29-Nov & 76.5 & 29.6 & 4 & 103.2 & 65.1 & 58.7 & 14.5 \\
\hline ALL & & & 1240.6 & 47.9 & 84 & 98.2 & 33.8 & & \\
\hline
\end{tabular}

A rain event is defined as having $>0.2 \mathrm{~mm}$ of rain with an interval of more than six hours from the last recorded rainfall using hourly data.

$a$ is the coefficient of variation $(\mathrm{CV})$ based on the $T_{h} / R_{g}$ ratio of all storage gauges $(\mathrm{n}=120)$.

$b$ is CV based on the average $T_{h} / R_{g}$ ratio for three storage gauges at 40 locations $(\mathrm{n}=40)$.

$c$ is the average of CV of three $T_{h} / R_{g}$ ratios at each location $(\mathrm{n}=40)$.

Figure 5 shows the box plots for the ratios of throughfall to gross rainfall $\left(T_{h} / R_{g}\right)$ for the 27 throughfall measurements and for 84 rain events (ALL). The $T_{h} / R_{g}$ ratios were not normally distributed (Shapiro-Wilk test, $p<0.05$ ), except for the $16^{\text {th }}$ throughfall measurement $(p=0.056)$ and ALL $(\mathrm{p}=0.141)$. The $T_{h} / R_{g}$ ratios for all rain events ranged from $27.4 \%$ to $204.7 \%$, with a mean and SD of $98.1 \%$ and $33.2 \%$, respectively. The maximum ratio was $986.5 \%$ at the fifth rain event. A $T_{h} / R_{g}$ ratio $>200 \%$ was observed for all measurements, except for the second. 
Through the gross rainfall contains of several rain events (Table 1 ), the $T_{h} / R_{g}$ ratio was significantly fit to the gross rainfall by logarithmic regressions $(y=57.3+$ $24.3 \log (x), n=27, r^{2}=0.195, p=0.021$; Fig. 6a). Likewise, the CV of the $T_{h} / R_{g}$ ratio of all storage gauges was significantly fit to the gross rainfall by logarithmic regres- sions $\left(y=89.0-18.2 \log (x), n=27, r^{2}=0.231, p=0.011\right.$; Fig. 6b). For gross rainfall $<25 \mathrm{~mm}$, the $\mathrm{CV}$ varied between $48.4 \%$ and $98.1 \%$ (mean: $68.1 \%, n=8$; Table 1 ). The CV varied between $43.3 \%$ and $81.1 \%$ (mean: $58.2 \%, n=16$; Table 1) when the gross rainfall ranged from 25 to $80 \mathrm{~mm}$. For gross rainfall $>80 \mathrm{~mm}$, the $\mathrm{CV}$ varied from $38.5 \%$ to

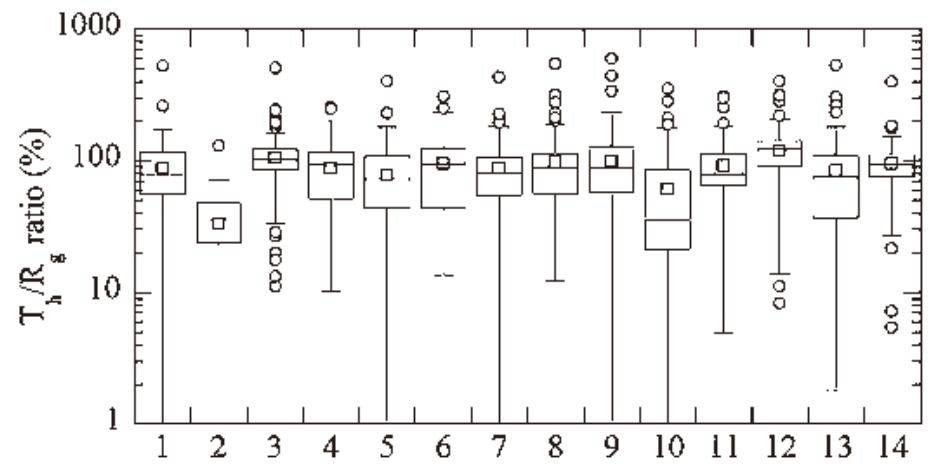

Box plot definition
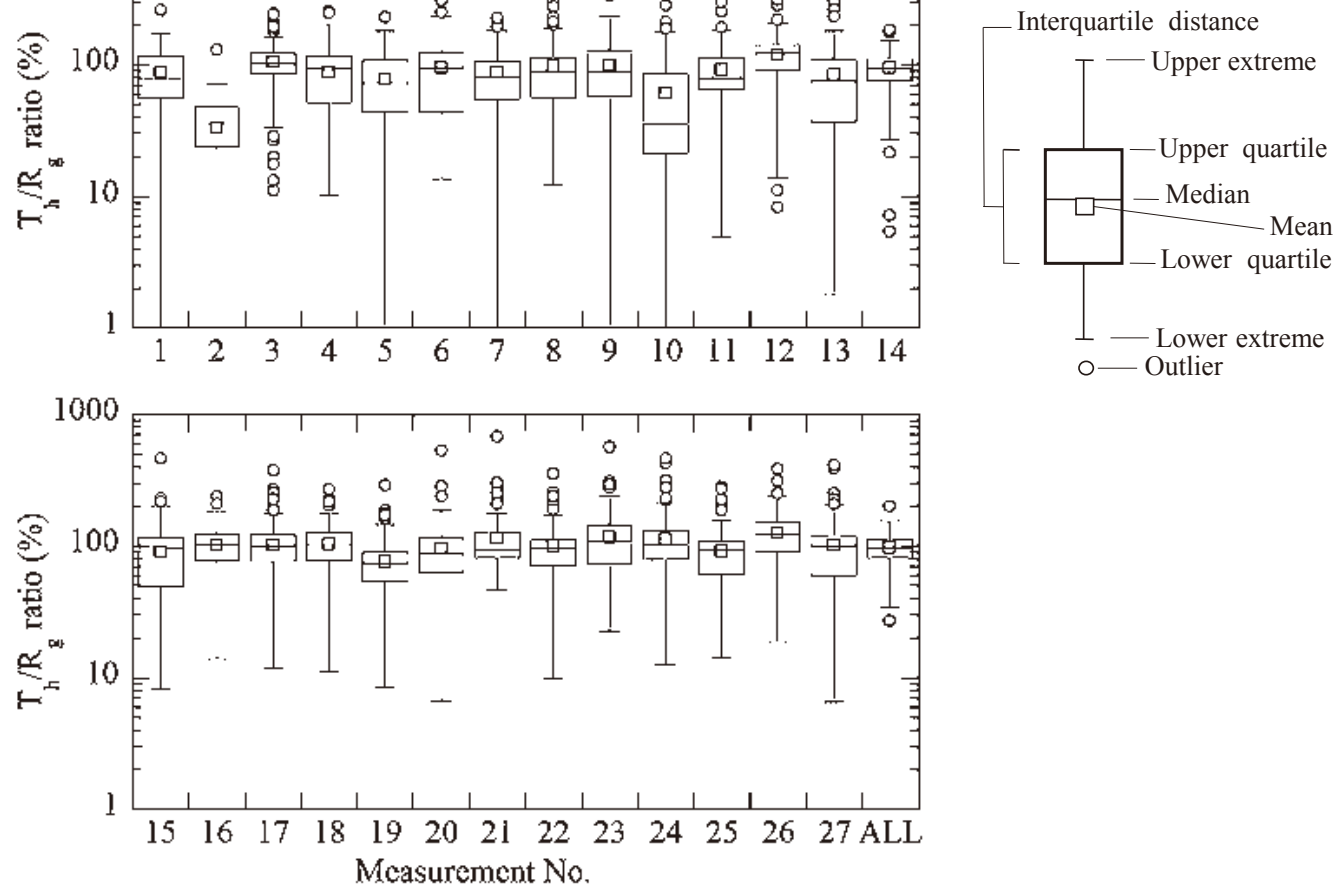

Fig. 5. Box plots for the ratio of throughfall to gross rainfall $\left(T_{h} / R_{g}\right)$ at 27 measurements and 84 rain events (ALL).
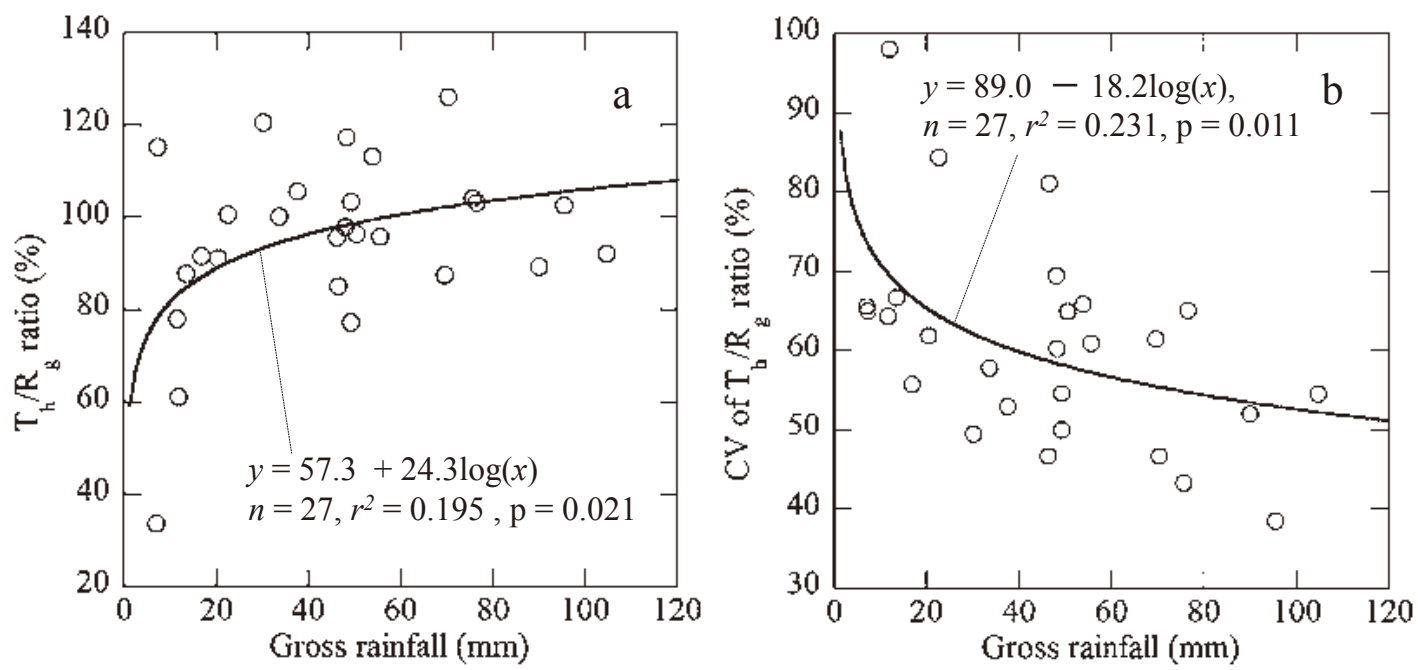

Fig. 6. (a) Relationship between the coefficient of variation $(\mathrm{CV})$ of the ratio of throughfall to gross rainfall $\left(T_{h} / R_{g}\right)$ and gross rainfall. (b) Relationship between the ratio of throughfall to gross rainfall $\left(T_{h} / R_{g}\right)$ and gross rainfall. 
$54.5 \%$ (mean: $48.3 \%, n=3$; Table 1 ). The mean of $\mathrm{CV}$ of three $T_{h} / R_{g}$ ratio at each location was smaller than the $\mathrm{CV}$ based on average of $T_{h} / R_{g}$ ratio for three storage gauges at 40 locations (Table 1). This result suggests that differences of vegetation at 40 locations have a greater effect on $T_{h} / R_{g}$ ratio than differences of vegetation above the three storage gauges at each location.

We calculated the number of collectors required at the $16^{\text {th }}$ throughfall measurement and for all the rain events because the $T_{h} / R_{g}$ ratios were normally distributed at those times (Shapiro-Wilk test). The numbers of collectors required at the $16^{\text {th }}$ throughfall measurement to estimate the mean throughfall with a precision of $10 \%$ and $5 \%$ at the $95 \%$ confidence level were 41 and 233 , respectively. The numbers of collectors required at all rain events to estimate the mean throughfall within $10 \%$ and $5 \%$ of the mean at the $95 \%$ confidence level were 32 and 180 , respectively. The design of an optimum design sampling scheme for estimating mean throughfall depended on the temporal scale of sampling and forest complexity (Zimmermann \& Zimmermann 2014). Twenty-five funnel-type collectors would be efficient to estimate mean throughfall for periods including many events in even complicated forests (Zimmermann \& Zimmermann 2014). Radrigo and Àvila (2001) also reported that $95 \%$ of the weekly distribution of mean throughfall does not exceed a 5\% error with more than 23 collectors. The confidence level in this study is larger than that in the previous studies (Radrigo \& Àvila 2001, Zimmermann \& Zimmermann 2014). On the other hand, based on an analysis of 20 studies, Iida (2009) reviewed the relationship between the confidence interval expressed as a percentage of mean throughfall and the total area used to collect rain water for throughfall measurements. Iida (2009) recommended setting up collectors over a total area of $>10,000 \mathrm{~cm}^{2}$ for throughfall measurements to measure the mean throughfall with a confidence interval within 5\%. We measured the throughfall using 120 simple storage rain gauges covering a total area of $7,140 \mathrm{~cm}^{2}$. These results suggest that the mean throughfall for the $16^{\text {th }}$ measurement and 84 rain events had a precision between 5\% and $10 \%$. Therefore, we subsequently analyzed the $T_{h} / R_{g}$ ratio of all rain events.

\section{Spatial distribution of throughfall at an abandoned skid trail}

Figure 7 shows the canopy openness just above the storage rain gauge points, the number of trees in each block and the number of large trees $(\mathrm{DBH}>20 \mathrm{~cm})$ beside each block, and the $T_{h} / R_{g}$ ratio for all rain events. No significant differences for the canopy openness and $T_{h} / R_{g}$ ratio were
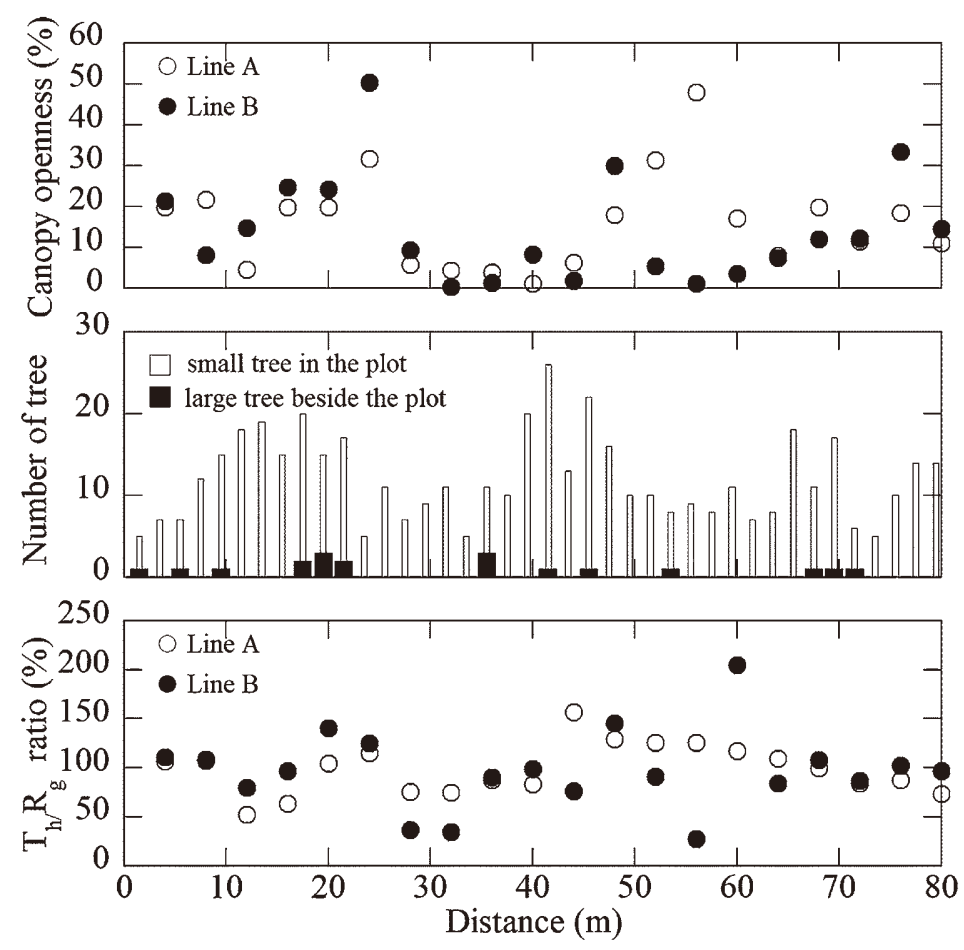

Fig. 7. Canopy openness just above the simple storage rain gauge points, the number of trees at each block, and distributions of the ratio of throughfall to gross rainfall $\left(T_{h} / R_{g}\right)$ for 84 rain events.

Lines A and B show the location of the simple storage rain gauges at the skid trail (refer to Fig. 1). 
observed between line A and line B (Mann-Whitney U test, canopy openness: $p=0.937, T_{h} / R_{g}$ ratio: $p=0.841$ ). There was no correlation between the number of trees and the $T_{h} / R_{g}$ ratio at the corresponding locations, but the $T_{h} / R_{g}$ ratio weakly correlated with canopy openness (Fig. 8). A similar relationship between the $T_{h} / R_{g}$ ratio and canopy openness was also observed in a natural tropical rain forest by Konishi et al. (2006), who pointed out the fact large canopy openness coinciding with a large throughfall value is quite natural because such positions were located under poorly developed canopy cover. We postulated that the occurrence of $T_{h} / R_{g}$ ratios $>100 \%$ at large canopy openness points may be due to the fact that horizontal rainwater movement created by the crown of a large tree likely caused an intense dripping zone (Manfroi et al. 2006).

Interestingly, high $T_{h} / R_{g}$ ratios $>150 \%$ were also observed even when canopy openness was small (Fig. 8). The maximum $T_{h} / R_{g}$ ratio at each observation ranged from $132 \%$ to $669 \%$, with a mean of $412 \%$ (Fig. 5). There seems to be another mechanism that causes intense dripping at such points. Based on field observations during storms, we found that a considerable amount of rainwater dropped under the bertam (i.e. Eugeissona tristis) and rattan (i.e. Daemonorops callicarpa, Calamus insignis) vegetation. Negishi et al. (2006) also observed a high amount of throughfall at the edge of a fern protrusion on a logging road abandoned for three years. This is a similar mechanism in which the understory vegetation increased throughfall on specific parts of the ground. At the abandoned skid trail, however, such a place corresponded to the outlier (Fig. 5). Then, such intense dripping points are not believed to have had much of an impact on the amount of throughfall at the abandoned skid trail.

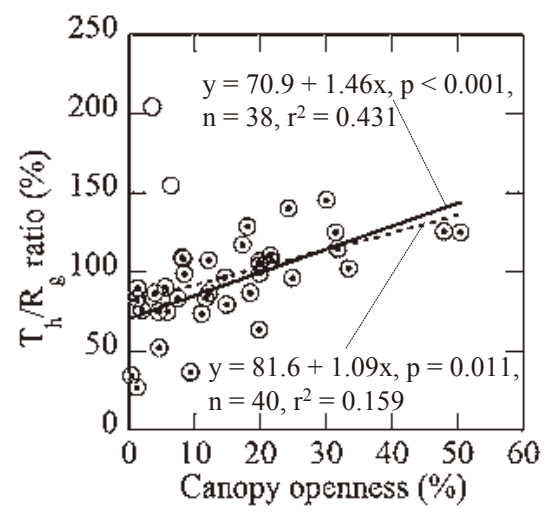

Fig. 8. Relationship between the ratio of throughfall to gross rainfall $\left(T_{h} / R_{g}\right)$ and canopy openness Open circles are plotted using all data.

Dots are plotted using data with the exception of data caused by intense dripping.
Canopy openness is not always the controlling factor of throughfall distribution (Konishi et al. 2006; Fig. 8) because it is two-dimensional information. However, hemispherical photographs can be collected easily and are useful to evaluate differences in tree structure in a tropical rain forest (Numata et al. 2006). It was also reported that there is a good correlation between canopy openness and throughfall (Noguchi \& Nishizono 2010). There is a relatively high correlation between canopy openness and the ratio of throughfall to rainfall with the exception of data caused by intense dripping (Fig. 8: $p<0.001, n=38$, $r^{2}=0.431$ ). These results suggest that canopy openness could be a useful index to estimate throughfall.

\section{Comparison of throughfall with other tropical rain forests}

The characteristics of vegetation along the skid trail were different from those in the regenerated secondary forest (Fig. 3). This result suggests that throughfall at a skid trail also differs from that in the forest. Hence, we compared throughfall in the regenerated secondary forest and at the abandoned skid trail in a tropical rain forest.

We measured daily throughfall 251 times in the regenerated secondary forest at the BTEW. The total amount of rainfall was $5,087 \mathrm{~mm}$, and the daily rainfall ranged from 0.2 to $144.8 \mathrm{~mm}$, with a mean (SD) of $20.3 \mathrm{~mm}(18.8 \mathrm{~mm})$. The total amount of throughfall or $T_{h} / R_{g}$ ratio at $\mathrm{T}_{\mathrm{h}}-1, \mathrm{~T}_{\mathrm{h}}-2$, $\mathrm{T}_{\mathrm{h}}-3$, and $\mathrm{T}_{\mathrm{h}}-4$ and the mean value were 4305.3 or 84.6 , 4082.2 or $80.2,4704.7$ or 92.5 , and 4514.3 or 88.7 and $4619.8 \mathrm{~mm}$ or $86.5 \%$, respectively. Figure 9 shows the box plots for the ratios of throughfall to gross rainfall $\left(T_{h} / R_{g}\right)$ at $\mathrm{T}_{\mathrm{h}}-1, \mathrm{~T}_{\mathrm{h}}-2, \mathrm{~T}_{\mathrm{h}}-3$, and $\mathrm{T}_{\mathrm{h}}-4$, and the mean value. A $T_{h} / R_{g}$ ratio $>200 \%$ was also observed for all locations except $T_{h}-1$. Significant differences were observed between $T_{h}-2$ and $T_{h}-3$ with one-way ANOVA followed by Scheffe's post hoc test. No significant differences were observed among other groups (Fig. 9).

The mean $T_{h} / R_{g}$ ratio $(98.2 \%)$ obtained at the abandoned skid trail was the largest ever reported for several forest types in Malaysia (Table 2). The mean ratio was larger than those observed in past reports even if based on the precision of $T_{h} / R_{g}$ ratio ranging from $5 \%$ to $10 \%$, as was indicated in the preceding section. Throughfall on the abandoned skid trail (mean: 98.1\%; Fig. 5) was greater than that in the tropical rain forest (mean: $86.5 \%$; Fig. 9). The difference of the mean of both was $11.6 \%$, which corresponds to $269.2 \mathrm{~mm}$ per year based on the 11-year period (1990-2000) of rainfall observation.

The $T_{h} / R_{g}$ ratio for a young secondary tropical forest (less than 5 years old) in Panama was more than 93\%. After only a decade, the ratio approached levels (less than 85\%) that are typical for mature forests. This is because tropical forest structure changes considerably during early succes- 

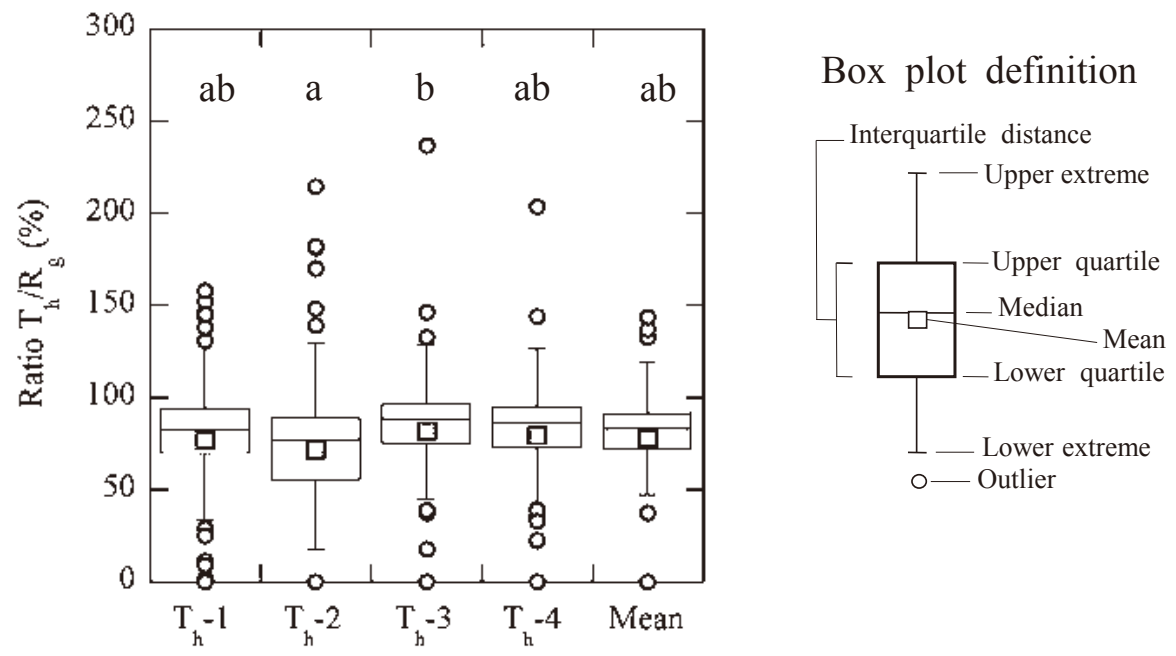

Fig. 9. Box plots for the ratio of throughfall to gross rainfall $\left(T_{h} / R_{g}\right)$ at 251 measurements in an old-growth forest.

Letter shown by the figure is the results of one-way ANOVA followed by Scheffe's post hoc test for multiple comparisons. Different letters indicate statistical differences among the groups.

Table 2. Throughfall observations for various forest types in Malaysia

\begin{tabular}{|c|c|c|c|c|c|}
\hline Reference & Forest type & $\begin{array}{l}\text { Number of } \\
\text { gauges }\end{array}$ & $\begin{array}{l}\text { Measurement } \\
\text { period }\end{array}$ & $\begin{array}{c}\text { Mean ratio of } \\
T_{h} / R_{g}(\%)\end{array}$ & $\begin{array}{l}\text { Total collecting } \\
\text { area }\left(\mathrm{cm}^{2}\right)\end{array}$ \\
\hline $\begin{array}{l}\text { Bidin \& Chappell (2004), } \\
\text { Chappell et al. (2001) }\end{array}$ & Lowland dipterocarp & $20-105$ & 12-month & $81.6-92.0$ & $3,534-18,555$ \\
\hline Burghouts et al. (1998) & Lowland dipterocarp & 30 & 13-month & 81 & 10,391 \\
\hline Konishi et al. (2006) & Primary lowland mixed dipterocarp & 100 & 3-month & 80.8 & 40,649 \\
\hline Manokaran (1979) & Primary lowland mixed dipterocarp & 13 & 12-month & 77.6 & 8,321 \\
\hline Manfroi et al. (2006) & Lowland evergreen & 60 & 6-month & 87.1 & 19,997 \\
\hline Sinun et al. (1992) & Lowland dipterocarp & 40 & 13-month & 80.7 & No record \\
\hline Siti et al. (2012) & Young Hopea Odorata plantation & $126-144$ & 15-month & $77.4-83.2$ & $50,099-57,256$ \\
\hline $\begin{array}{l}\text { Yusop (1996), } \\
\text { Yusop et al. (2003) }\end{array}$ & Lowland tropical rainforest & 4 & 24-month & $84-87$ & 1,297 \\
\hline \multirow[b]{2}{*}{ This study } & Lowland tropical rainforest & 4 & 24-month & 86.5 & 1,297 \\
\hline & $\begin{array}{l}\text { Abandoned skid trail in lowland } \\
\text { tropical rainforest }\end{array}$ & 120 & 6-month & 98.2 & 7,140 \\
\hline
\end{tabular}

sion (Zimmermann et al. 2013). The oldest trees along the abandoned skid trail might be 41 years old as the skid trail was abandoned 41 years after forest harvesting. However, the mean $T_{h} / R_{g}$ ratio was relatively larger than the $T_{h} / R_{g}$ ratio for the much younger secondary forest in Panama.

It was reported that wind speed is generally low in tropical rain forests (Tani et al. 2003, Yasuda et al. 2003). Hence, we did not discuss whether wind speed and direction had an effect on throughfall in this study. The many possible reasons why more rainfall reached the abandoned skid trail are related to the unique tree composition at the skid trail compared with that inside the forest. There was no significant difference between the canopy openness of the skid trail and that of the forest, as mentioned previously. Despite this result, vegetation along the skid trail comprised shorter trees with smaller DBH (Fig. 3). Therefore, throughfall at the skid trail tended to be larger than that under the canopy of a regenerated secondary tropical forest because the skid trail is covered only by a portion of the canopy from neighboring large trees. Such large trees seem 
to supply more rainfall given the relatively bending nature of the stem. Thus, the width of the area that received rain water for throughfall at the skid trail was greater than the width of the skid trail itself (Fig. 10). On the other hand, the aerodynamic resistance in shorter trees is higher than that in taller trees (Hattori 1985). Hence, the aerodynamic resistance at the abandoned skid trail is higher than that around the forest because the tree height at the abandoned skid trail was shorter than those around the forest (Fig. 3). These results suggest that canopy interception loss at the abandoned skid trail is smaller than that in the forest. This is another reason for higher throughfall at the abandoned skid trail than in the tropical rain forest.

\section{Conclusions}

Knowledge of throughfall at abandoned skid trails in tropical forests is extremely scarce. All trees $\geq 1 \mathrm{~m}$ in height in the plot were identified at the species level, and their diameter at breast height (DBH), height and throughfall were measured at a skid trail left abandoned 41 years after forest harvesting in Peninsular Malaysia. A considerable amount of rainwater was dropped under bertam (i.e. Eugeissona tristis) and rattan (i.e. Daemonorops callicarpa, Calamus insignis) vegetation. The $T_{h} / R_{g}$ ratio correlated with canopy openness except at rainwater dropping points. The mean $T_{h} / R_{g}$ ratio is $98.1 \%$, which is the largest ever reported among tropical forest sites in Malaysia. The diversity of vegetation species at the skid trail was similar to that in the regenerated secondary tropical forest plot. An abundant canopy species less than $5 \mathrm{~cm}$ in DBH (e.g. Koompassia malaccensis) that is classified as an emergent species group has regenerated on the abandoned skid trail. However, the trees along the skid trail are smaller in $\mathrm{DBH}$ and shorter than those in the regenerated secondary forest. Our results suggest that such forest structure at the old abandoned skid trail is responsible for the high $T_{h} / R_{g}$ ratio.

\section{Acknowledgments}

We wish to thank the State Forest Department of Selangor for granting permission to conduct the study at the Bukit Tarek Experimental Watershed. Thanks are due to all the personnel at the Forest Research Institute Malaysia for their efforts in data collection. Data were obtained during the project titled "Development of regeneration technology in consideration for preservation of forest environment functions (2001-2004)", which was funded by Japan International Research Center for Agricultural Sciences. This is a joint research project between the Forest Research Institute Malaysia (FRIM), Universiti Putra Malaysia (UPM), and the National Institute of Environmental Studies (NIES). This study was also supported by the Japan Society for the Promotion of Science (JSPS) for KAKENHI (24255014).

\section{References}

Baharuddin, K. et al. (1995) Surface runoff and soil loss form a

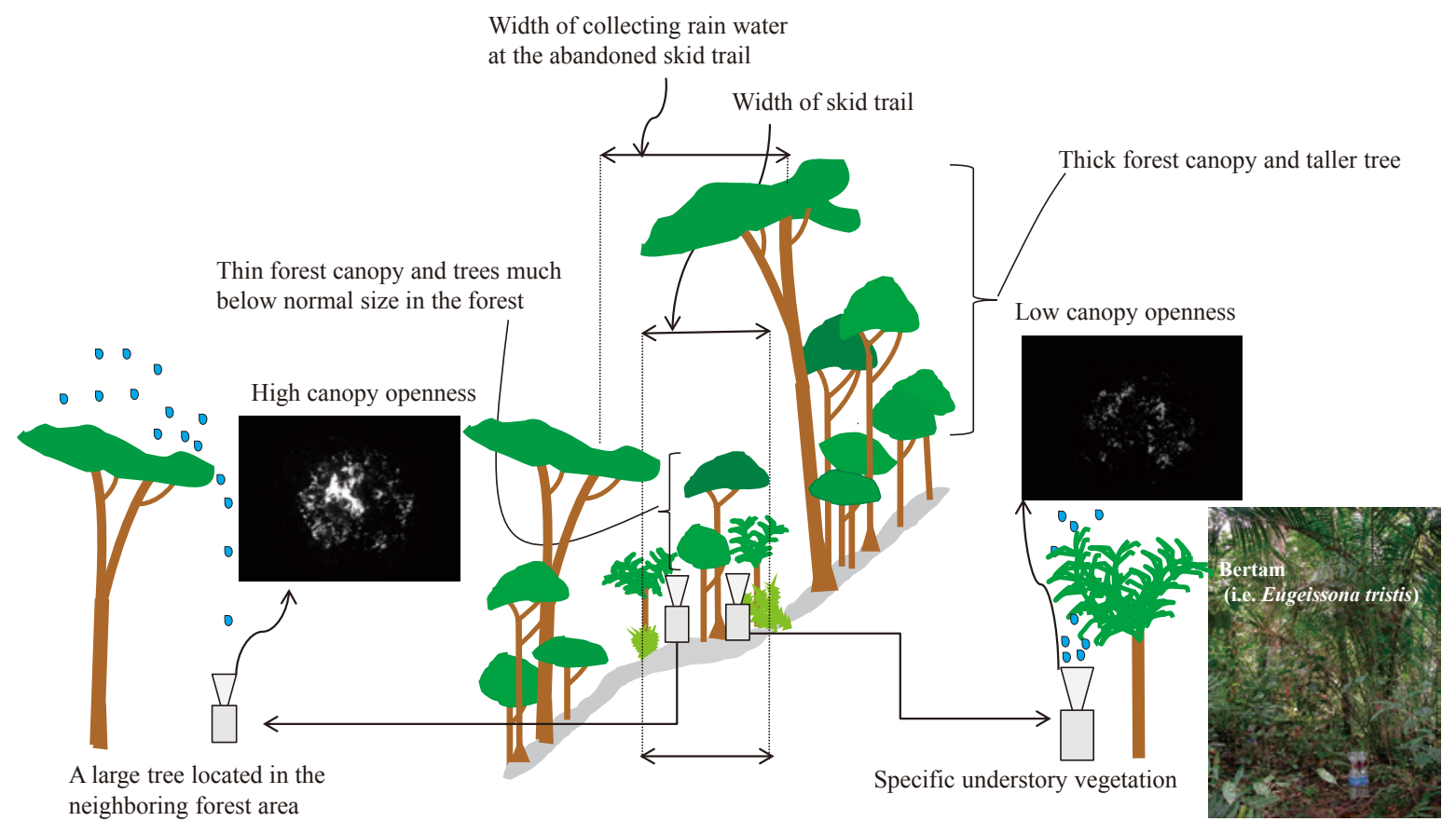

Fig. 10. Schematic of the spatial distribution of throughfall at the skid trail in a tropical rain forest. 
skid trail and a logging road in a tropical forest. J. Trop. For. Sci., 7, 558-569.

Bidin, K. \& Chappell, N.A. (2004) Sub-canopy rainfall and wet canopy evaporation in a selectively-logged rainforest, Sabah, Malaysia. In Water: forestry and land use perspectives. ed. Abdul Rahim, N., IHP-VI, Technical Documents in Hydrology, No. 70. UNESCO, Paris, 69-85.

Burghouts, T.B.A. et al. (1998) Spatial heterogeneity of element and litter turnover in a Bornean rain forest. J. Trop. Ecol., 114, 477-506.

Carlyle-Moses, D.E. et al. (2004) Throughfall and throughfall spatial variability in Madrean oak forest communities of northeastern Mexico. J. Hydrol., 297, 124-135.

Chappell, N. A. et al. (2001) Modelling rainfall and canopy controls on net-precipitation beneath selectively-logged tropical forest. Plant Ecology, 153, 215-229.

Davie, T. (2002) Fundamentals of hydrology. Routledge Taylor \& Francis Group, London and New York, 169.

Gomi, T. et al. (2006) Sediment and wood accumulations in humid tropical headwater streams: effects of logging and riparian buffers. Forest Ecol. Manag., 224, 166-175.

Hattori, S. (1985) Explanation on derivation process of equations to estimate evapotranspiration and problems on the application to forest stand. Bull. For. For. Prod. Res. Inst. 332, 139-165.

Iida, S. (2009) Rainfall redistribution by the vegetation. In Hydrologic Science, eds. Sugita, M \& Tanaka, T., Kyoritsu Shuppan Co., Ltd., 103-117.

Kimmins, J.P. (1973) Some statistical aspects of sampling throughfall precipitation in nutrient cycling studies in British Columbian coastal forests. Ecology, 54, 1008-1019.

Kobayashi, S. (2004) Toward the synthesis of rehabilitation technology and the response option for global environmental conservation. In Proceedings of Rehabilitation of Degraded Tropical Forests, Southeast Asia 2004. eds. Matsumoto, Y. et al., FFPRI, Tsukuba, Japan, 1-10.

Konishi, S. et al. (2006) Characteristics of spatial distribution of throughfall in a lowland tropical rainforest, Peninsular Malaysia. Forest Ecol. Manag., 224, 19-25.

Manokaran, N. (1979) Stemflow, throughfall and rainfall interception in Peninsular Malaysia. Malay. Forester, 42, 174-201.

Manokaran, N. \& Swaome, M. D. (1994) Population dynamics of trees in dipterocarp forest of Peninsular Malaysia. Malayan Forest Records No. 40, Forest Research Institute Malaysia, Kuala Lumpur, 173.

Manfroi et al. (2006) Comparison of conventionally observed interception evaporation in a $100-\mathrm{m}^{2}$ subplot with that estimated in a 4-ha area of the same Bornean lowland tropical forest. J. Hydrol., 329, 329-349.

Negishi, J.N. et al. (2006) Ecological roles of roadside fern (Dicranopteris curranii) on logging road recovery in Peninsular Malaysia: Preliminary results. Forest Ecol.
Manag., 224, 176-186.

Negishi, J.N. et al. (2007) Stormflow generation involving pipe flow in a zero-order basin of Peninsular Malaysia. Hydrol. Process., 21, 79-806.

Negishi, J.N. et al. (2008) Contribution of intercepted subsurface flow to road runoff and sediment transport in a logging-disturbed tropical catchment. Earth Surf. Process. Landforms, 33, 1174-1191.

Niiyama, K. et al. (2003) Regeneration of a clear-cut plot in a lowland dipterocarp forest in Pasoh Forest Reserve, Peninsular Malaysia. Pasoh: Ecology of a lowland rain forest in Peninsular Malaysia, Springer, Tokyo, Japan, 259-268.

Noguchi, S. \& Nishizono T. (2010) The comparison of throughfall between evergreen coniferous and deciduous broad-leaved forests during the snow cover period. J. Jpn. For. Soc. 92, 29-34 [In Japanese with English summary].

Noguchi, S. et al. (1996) Rainfall characteristics of a tropical rain forest and temperate rain forest: comparison between Bukit Tarek in Peninsular Malaysia and Hitachi Ohta in Japan. J. Trop. For. Sci., 9, 206-220.

Noguchi, S. et al. (2004a) Evapotranspiration estimates of tropical rain forest, Bukit Tarek Experimental Watershed in Peninsular Malaysia, using the short-time period waterbudget method. J. Japan Soc. Hydrol. Water Resources, 17, 482-492.

Noguchi, S. et al. (2004b) Effect of forest harvesting on tree species composition at riparian zone in a tropical rain forest. In Proceedings of Rehabilitation of Degraded Tropical Forests, Southeast Asia 2004. eds. Matsumoto, Y. et al. FFPRI, Tsukuba, Japan, 43-48.

Numata, S. et al. (2006) Canopy gap dynamics of two different forest stands in a Malaysian lowland rain forest. J. Trop. For. Sci., 18, 109-116.

Ohnuki, Y. et al. (2010) Sediment discharge through buffer zones in a tropical rainforest of Peninsular Malaysia. JARQ, 44, 187-196.

Okuda, T. et al. (2003) Effect of selective logging on canopy and stand structure and tree species composition in lowland dipterocarp forest in peninsular Malaysia. Forest Ecol. Manag., 175, 297-320.

Radrigo, A. \& Àvila, A. (2001) Influence of sampling size in the estimation of mean throughfall in two Mediterranean holm oak forests. J. Hydrol., 243, 216-227.

Saifuddin, S. et al. (1991) Establishment and physical characteristics of Bukit Tarek watershed. FRIM Res. Pam., 110, 1-51.

Sidle, R.C. et al. (2004) Sediment pathways in a tropical forest: effects of logging roads and skid trails. Hydrol. Process., 18, 703-720.

Sinun, W. et al. (1992) Throughfall, stemflow, overland flow and throughfall in the Ulu Segama rain forest, Sabah, Malaysia. Phil. Trans. R. Soc. Land. B 335, 389-395.

Siti Aisah S. et al. (2012) Rainfall partitioning in a young Hopea Odorata plantation. J. Trop. For. Sci., 24, 147-161. 
Tani, M. et al. (2003) Characteristics of energy exchanges and surface conductance of a tropical rain forest in Peninsular Malaysia. Pasoh: Ecology of a lowland rain forest in Peninsular Malaysia. Springer, Tokyo, Japan, 73-88.

Yasuda, Y. et al. (2003) Measurement of $\mathrm{CO}_{2}$ flux above a tropical rain forest at Pasoh in Peninsular Malaysia. Agric. For. Meteorol., 114, 235-244.

Yusop, Z. (1996) Nutrient cycling in secondary rain forest catchments of Peninsular Malaysia. Ph.D. thesis, University of Manchester, Manchester, UK.

Yusop, Z. et al. (2003) Rainfall partitioning in an old growth tropical rain forest. In Proceedings of the international conference on forest and forest products research. (CFFPR 2001) Topical forestry research in the new millennium:
Meeting demands and challenges, eds. Azmy $\mathrm{Hj}$. Mohamed et al., Forest Research Institute Malaysia, Kuala Lumpur, Malaysia, 24-29.

Wiafe, E.D. (2014) Tree regeneration after logging in rain-forest ecosystem. Res. J. Biol., 2, 18-28.

Ziegler, A.D. et al. (2007) Persistence of road runoff generation in a logged catchment in Peninsular Malaysia. Earth Surf. Process. Landforms, 33, DOI: 10.1002/esp.1508

Zimmermann, A. \& Zimmermann, B. (2014) Requirements for throughfall monitoring: The roles of temporal scale and canopy complexity. Agric. For. Meteorol., 189-190, 125-139.

Zimmermann, B. et al. (2013) Changes in rainfall interception along a secondary forest succession gradient in lowland Panama. Hydrol. Earth Syst. Sci., 17, 4659-4670. 